пасажирських перевезень в умовах трансформаційних змін [Текст]: Дис. ... к.е.н.: 08.00.04 / Матусевич Олексій Олександрович: ДНУЗТ.

Дніпропертовськ, 2015. - 177 с.

12 Пасажирська компанія дозволить більш ефективно реагувати на зростання пасажиропотоку [Електронний ресурс]. Режим доступу: http://www.uz.gov.ua/press_center/up_to_date _topic/447430/

13 Петренко, О.О. Пасажирські залізничні перевезення в Україні: сучасний стан і перспективи розвитку [Текст] / O.O. Петренко // Економіка та управління національним господарством. - 2016. - Вип. 10. - C. 47-52.

14 Реформи залізничного транспорту [Електронний ресурс] // Міністерство інфраструктури України. - Режим доступу: http://mtu.gov.ua/content/reformizaliznichnogo-transportu.html

15 Стратегічний план розвитку залізничного транспорту на період до 2020 року [Електронний ресурс] // Міжнародний техніко-економічний журнал «Українська залізниця». - Режим доступу: http://ukrrailways.com/2-uncategorised/1706strategic-plan-2020-p1.html

16 «Укрзалізниця» значительно поднимет цену на перевозки, если станет частной (28.10.2015) [Електронний ресурс]. - Режим доступу: http://dnpr.com.ua/content/ukrzaliznicyaznachitelno-podnimet-cenu-na-perevozki-eslistanet-chastnoy

17 Чаркіна, Т.Ю. Методика проведення досліджень стосовно підвищення конкурентоспроможності пасажирських перевезень [Текст] / Т.Ю. Чаркіна //Вісник економіки транспорту i промисловості. - 2011. - №36. - С.289-296.

18 Чим Україні загрожує реформа залізниці? (січень 2015) [Електронний ресурс]. - Режим доступу: http://socportal.info/2015/08/06/chim-ukrayinizagrozhuye-reforma-zaliznitsi.html

19 Шерепа, К. Аналіз функціонування пасажирського залізничного комплексу країни [Текст] / К. Шерепа // Збірник наукових праць ДЕТУТ. Серія «Економіка і управління». - 2012. Вип. 19. - С.231-235.

УДК 330.34:656.2

\title{
КОНЦЕПТУАЛЬНІ ЗАСАДИ ІНФРАСТРУКТУРНОЇ БЕЗПЕКИ НА ЗАЛІЗНИЧНОМУ ТРАНСПОРТІ
}

\author{
Шраменко О.В., к.е.н., доцент, \\ Хорошаєва С.В., магістр (УкрДУЗТ)
}

В статті показана значущість транспортної інфраструктури в сучасних умовах. Відмічено, щзо іï розвиток $\epsilon$ передумовою для формування глобального світового господарства. Обтрунтовано необхідність створення системи інфраструктурної безпеки залізничного транспорту. Наведено ризики інфраструктури, що порушують ї̈ безпеку. Надано характеристику основним видам інфраструктурної безпеки. Виділено принщипи та підходи забезпечення безпеки на залізничному транспорті.

Ключові слова: безпека, інфраструктура, залізничний транспорт.

(C) Шраменко О.В., Хорошаєва С.В.
Вісник економіки транспорту і промисловості № 57, 2017 97 


\title{
КОНЦЕПТУАЛЬНЫЕ АСПЕКТЫ ИНФРАСТРУКТУРНОЙ БЕЗОПАСНОСТИ ЖЕЛЕЗНОДОРОЖНОГО ТРАНСПОРТА
}

\author{
Шраменко Е.В., к.э.н., доцент, \\ Хорочаева Е.В., магистр (УкрГУЖТ)
}

В статье показана значимость транспортной инфраструктуры в современных условиях. Отмечено, что её развитие является предпосылкой для формирования глобального мирового хозяйства. Обоснована необходимость создания системь инфраструктурной безопасности железнодорожного транспорта. Приведень риски инфраструктуры, которые нарушают ее безопасность. Дана характеристика основным видам инфраструктурной безопасности. Выделены принцииьы и подходы обеспечения безопасности на железнодорожном транспорте.

\section{Ключевые слова: безопасность, инфраструктура, жселезнодорожный транспорт. \\ CONCEPTUAL ASPECTS OF INFRASTRUCTURE SECURITY FOR RAILWAY TRANSPORT}

\author{
Shramenko E. V., candidate of Economic Sciences, associate Professor, \\ Horoshaeva E.V., master (USURT)
}

The article shows the importance of transport infrastructure in modern conditions. Noted, that its development is a prerequisite for the global world economy formation. It is proved the necessity of creation of infrastructure security system for railway transport. Given the infrastructure risks, that violates its security. Given the characteristic for the main types of infrastructure security. Selected principles and approaches for ensuring of security on railway transport. It is concluded that only with guaranteed high-level infrastructure security it is possible to attract international transit traffic. In this regard, it is the most important priority of the reorganization of the infrastructure management systems. An effective system of infrastructure security is intended to ensure both the success functioning of railway transport and the efficiency of the nation's economics as a whole.

Key words: security, infrastructure, railway transport.

\section{Постановка}

проблеми. Транспортна система є однією зі значущих складових глобального інфраструктурноекономічного середовища. Створюючи умови для переміщення продукції, а також мобільності населення i факторів виробництва, транспортна система виступає ланкою, яка забезпечує цілісність та єдність світової економіки. Саме розвиток транспортної інфраструктури став передумовою для формування глобального світового господарства. Сьогодні транспортна інфраструктура зберігає за собою цю функцію, дозволяючи використовувати переваги міжнародного поділу праці та посилюючи процеси інтернаціоналізації світових зв'язків.

Крім того, останні роки характеризувалися безпрецедентними структурними змінами в сфері залізничного транспорту в світі та в Україні. В результаті цих змін відбулося відділення управління інфраструктурою та експлуатаційною діяльністю.

$$
\text { Найбільш значущим стало }
$$
створення єдиного ринку з відповідним відкриттям національних кордонів. 
Транспортна політика європейських країн спрямована на створення загальноєвропейського залізничного ринку, в том числі за допомогою розробки єдиного для усіх об'єктів європейської залізничної інфраструктури законодавства, яке визначає права та відповідальність компаній, які займаються iї експлуатацією.

Підвищення ступеню інтеграції, яке відбувається останнім часом в рамках світового економічного простору, посилює роль транспортної інфраструктури та іï безпеки 3 метою забезпечення ефективного функціонування інтеграційних об'єднань.

До сучасних тенденцій розвитку міжнародної транспортної інфраструктури належать також тенденції поширення логістики. Країни світу зацікавлені у якісних міжнародних транспортних перевезеннях, які забезпечують збереження вантажів, високу швидкість перевезень тощо. Для цього необхідний розвиток міжнародної транспортної інфраструктури, яка здатна забезпечити відповідний рівень безпеки.

Слід відмітити, що згідно 3 Директивою 2008/114 СС [1] транспорт є одним 3 двох секторів, що належать до об’єктів загальноєвропейської критичної інфраструктури. Європейська критична інфраструктура - це об'єкт, система або їі частина, яка має суттєве значення для підтримки суспільно корисних функцій, здоров'я, безпеки, економічного та соціального благополуччя населення і не буде призводити до порушення та руйнування їх функціонування.

Світові тенденції обумовлюють пріоритетні проекти, які реалізуються Міністерством інфраструктури України. Вони пов'язані з розвитком швидкісного руху, побудовою міжнародних транспортних коридорів та розвитком мультимодальних перевезень, але не можуть бути реалізовані через незадовільний стан залізничної інфраструктури.
В зв'язку з цим питання створення системи інфраструктурної безпеки на сучасному етапі набувають все більшої актуальності.

Аналіз останніх досліджень. Багато праць спрямовані на вирішення проблем економічної безпеки залізничного транспорту. Вагомий внесок в цьому напрямку належить вченим школи Диканя В.Л.: Назаренко І.Л., Сухоруковій Т.Г., Воловельській І.В., Толстовій А.В. та ін. [2-5].

Безпека інфраструктури розглядається в роботах Журавльової Н.О., Касьянової Н.В., Біленко О.К. [6-8], але питання інфраструктурної безпеки залізничного транспорту потребують подальшої систематизації.

В зв'язку 3 цим метою статті $\epsilon$ розробка концептуальних засад забезпечення інфраструктурної безпеки залізничного транспорту.

Викладення основного матеріалу. Згідно $з$ Технічним регламентом безпеки інфраструктури залізничного транспорту безпека інфраструктури залізничного транспорту являє собою такий стан інфраструктури залізничного транспорту, при якому відсутній неприпустимий ризик, пов'язаний із заподіянням шкоди життю або здоров'ю громадян, майну фізичних або юридичних осіб, державного або муніципального майна, а також навколишньому середовищу, життю або здоров'ю тварин і рослин [9].

Інфраструктура залізничного транспорту включає в себе підсистеми інфраструктури залізничного транспорту, такі, як залізнична колія, залізничне електрозабезпечення, залізнична автоматика та телемеханіка, залізничний електрозв'язок, а також станційні будови, споруди та пристрої. Крім того, до об'єктів інфраструктури належать складові підсистем інфраструктури залізничного транспорту та їх елементи.

Як зазначалося в попередніх дослідженнях [10], стан інфраструктури залізничного транспорту України 
характеризується як незадовільний. В той же час провідні світові експерти вважають рівень розвитку інфраструктури ключовим фактором конкурентоспроможності економіки.

До ризиків інфраструктури вчені [8] відносять: великий рівень зносу інфраструктури; недостатня доступність інфраструктури (низький рівень розвитку інженерної інфраструктури, відсутність окремих елементів виробничої інфраструктури); недостатність потужностей (підключення до електромережі, комунікації); недостатня пропускна потужність (відсутність розвинутої дорожньої інфраструктури та зв'язку); вплив зовнішніх чинників (природних та техногенних).

Безпека інфраструктури потребує не тільки особливої системи оцінки іiі порогових значень, оскільки має найбільші глобальні, макроекономічні, технологічні та фінансові ризики, але i особливої форми управління. В кризових умовах інфраструктурні компанії не можуть скоротити витрати і чисельність персоналу пропорційно скороченню обсягу реалізації послуг, оскільки зобов'язані підтримувати стабільність і безпеку системи на колишньому рівні. Це одна 3 причин, за якою держава як власник більшості інфраструктурних компаній має ініціювати впровадження кризових моделей управління інфраструктурою.

Основними видами безпеки транспортної інфраструктури $\epsilon$ функціональна, екологічна і фінансово економічна.

\section{Функціональна}

безпека транспортної інфраструктури означає іiі стійку здатність задовольняти потреби інноваційного і соціально орієнтованого розвитку економіки і суспільства в якісних транспортних послугах на основі:

$\begin{array}{lrr}- & \text { формування } & \text { єдиного } \\ \text { транспортного } & \text { простору } & \text { на базі } \\ \text { збалансованого розвитку } & \text { ефективної } \\ \text { транспортної інфраструктури; } & \end{array}$

- забезпечення доступності, обсягу та конкурентоспроможності транспортних послуг за критеріями якості для вантажовласників на рівні потреб інноваційного розвитку економіки країни; - забезпечення доступності та якості транспортних послуг для населення;

- інтеграції у світовий транспортний простір i реалізації транзитного потенціалу країни;

- підвищення рівня безпеки транспортної системи;

- зниження шкідливої дії транспорту на навколишнє середовище.

Екологічна безпека найчастіше визначається як сукупність станів, процесів і дій, які забезпечують екологічний баланс в навколишньому середовищі та не приводять до життєво важливих збитків природному середовищі та людині. Це також процес забезпечення захищеності життєво важливих інтересів особи, суспільства, природи, держави i всього людства від реальних або потенційних загроз, створюваних антропогенним або природним впливом на навколишнє середовище. Екологічна безпека транспортної інфраструктури критична в частині автомобільного та повітряного транспорту. Найбільш екологічним видом транспорту $\epsilon$ залізничний транспорт [7].

Фінансово-економічна безпека призвана знизити частку транспортних i житлово-комунальних послуг в ціні продукції і сімейних доходів і в той же час гарантувати рентабельність, достатню для забезпечення безпеки інфраструктури. Досі ця проблема вирішується в «коридорі» зростання тарифів, рівня інфляції та інвестиційної складової в тарифі, що не зменшує вартість інфраструктурної послуги в кінцевому продукті і не стимулює іiі інноваційне оновлення [6].

Фінансово-економічна безпека інфраструктури передбачає наявність інвестицій, достатніх для іiї сталого 
функціонування та розвитку та їх оскільки для інфраструктури ефективне використання, а також стале характерними є висока капіталомісткість, фінансування поточних витрат при тривалими строками окупності вкладень конкурентних цінах на інфраструктурний та високим інвестиційним ризиком.

продукт.

Фінансово-економічна безпека

Принципи забезпечення безпеки інфраструктури являє собою особливу транспорті представлено в таблиці 1. теоретичну i практичну проблему,

Таблиияя 1

Принциипи забезпечення безпеки інфраструктури на залізничному транспорті

\begin{tabular}{|c|c|}
\hline Принципи & Визначення \\
\hline 1 & 2 \\
\hline $\begin{array}{c}1 \text { Наявність балансу між } \\
\text { витратами і заданим } \\
\text { рівнем безпеки }\end{array}$ & $\begin{array}{l}\text { Йдеться насамперед про адресність та правильності планування } \\
\text { коштів. Позитивний результат багато в чому забезпечений } \\
\text { адресним вкладенням інвестицій в інфраструктуру і рухомий } \\
\text { склад. Удосконалюючи свою роботу над витратами, залізниця } \\
\text { обов'язково повинна враховувати необхідні рівні інвестицій та } \\
\text { капітального ремонту, що забезпечують подальший оновлення } \\
\text { інфраструктури і рухомого складу, а також добиватися } \\
\text { максимального збереження передбачених обсягів державного } \\
\text { фінансування для розвитку галузі. }\end{array}$ \\
\hline $\begin{array}{c}2 \text { Впровадження методів } \\
\text { інтелектуального } \\
\text { управління і контролю. }\end{array}$ & $\begin{array}{l}\text { На залізницях повинні бути створені центри моніторингу } \\
\text { пристроїв автоматики і телемеханіки, контроль за роботою } \\
\text { машиністів спеціального автомобільного рухомого складу, який } \\
\text { ведеться з використанням автоматизованих систем управління. } \\
\text { Сьогодні завдання департаментів, дирекцій і залізниць полягає в } \\
\text { забезпеченні активного впровадження методів інтелектуального } \\
\text { управління та контролю на всій мережі. }\end{array}$ \\
\hline $\begin{array}{c}3 \text { Розвиток лідерських } \\
\text { якостей керівників }\end{array}$ & $\begin{array}{l}\text { Компанія робить ставку на лідерство як основу майбутніх } \\
\text { досягнень компанії і відкриває широкі можливості для навчання } \\
\text { керівників сучасних стилів та методів управління, в тому числі } \\
\text { менеджменту безпеки руху. Наявність сильних лідерів, які } \\
\text { реалізують себе через досягнення цілей компанії, зміцнює } \\
\text { ринкові позиції залізниці, дозволяє забезпечити перехід до } \\
\text { гарантованої безпеки. }\end{array}$ \\
\hline $\begin{array}{c}4 \text { Комплексний аналіз } \\
\text { стану технічних засобів, } \\
\text { оснащеності і на цій } \\
\text { основі прогнозування } \\
\text { рівня безпеки. }\end{array}$ & $\begin{array}{l}\text { На підставі цього принципу проводиться діагностика технічних } \\
\text { засобів, оснащеності залізниці. За результатами цього аналізу } \\
\text { робляться висновки і приймаються ті або інші рішення. Цей } \\
\text { метод дає можливість уникнути порушення і зменшити події на } \\
\text { залізницях. }\end{array}$ \\
\hline $\begin{array}{c}5 \text { Побудова } \\
\text { менеджменту безпеки }\end{array}$ & $\begin{array}{l}\text { Необхідно пам'ятати, що безпека замислюється, забезпечується } \\
\text { і вимірюється на всіх етапах життєвого циклу того або іншого } \\
\text { пристрою. } \\
\text { Керівник невідповідностей, а в разі появи якоїсь } \\
\text { невідповідності реєструвати іiі і розробляти коригувальні } \\
\text { структурного підрозділу сьогодні зобов'язаний сам проводити } \\
\text { аналіз ризиків виникнення заходи } 3 \text { використанням відомих } \\
\text { методик. Однак прикладів такого підходу поки дуже мало. }\end{array}$ \\
\hline
\end{tabular}

В арсеналі компанії формується широкий спектр систем безпеки, на базі 
яких може бути створено комплекс технічних пристроїв, що відповідає необхідним вимогам щодо функціональної безпеки при оптимізації використовуваних інвестиційних ресурсів для конкретних умов застосування. Диференційована оцінка умов повинна враховувати відповідні ризики при різних обсягах та умовах виконуваної роботи, швидкості руху, реальний рівень надійності технічних засобів, а також ряд інших факторів.

У світі існує три пануючих підходи до забезпечення безпеки взагалі, та інфраструктури зокрема.

Згідно 3 першим акцент робиться на технічних засобах i рішеннях. При цьому передбачається, що ідеальна техніка і різні технічні системи ведуть до підвищення рівня безпеки.

Другий підхід робить акцент на людському факторі. При його реалізації створюється величезна кількість правил, яким працівник має дотримуватися.

При третьому підході акцент зосереджений на системі управління. Цей підхід найбільш популярний.

У багатьох зарубіжних країнах (Франції, Німеччині, Англії, Швеції) для забезпечення безпеки використовують кількісні методи аналізу і ризику. В Італії і Іспанії користуються професійними оцінками. Належний рівень безпеки руху досягається за рахунок мобілізації персоналу, жорсткого контролю за дотриманням правил. Усвідомлюється необхідність переходу від фрагментарних робіт із забезпечення гарантованої безпеки i надійності перевізного процесу на основі кількісних моделей ризиків, технічного аудиту до системних.

Методологія управління ризиками цілком базується на сучасних технологіях. При цьому відбувається поступовий перехід від системи контролю над станом безпеки в технологічних операціях до системи визначення рівня впливу факторів небезпеки на результати економічної діяльності транспорту.
Висновки. Таким чином, у сучасних умовах тільки при гарантовано високому рівні безпеки інфраструктури можливе залучення міжнародного транзитного вантажопотоку. Тому одним 3 пріоритетів повинні стати не тільки дотримання сучасних стандартів якості надаваних послуг при транспортуванні вантажів у міжнародних транспортних коридорах, але i підвищення безпеки перевезень, що може дати відчутний фінансовий результат вітчизняним транспортним компаніям.

Необхідний рівень безпеки залишається найважливішим пріоритетом структурної реорганізації систем управління інфраструктурою. Рівень безпеки інфраструктури залізничного транспорту впливає на фінансовоекономічні показники його роботи, позначається на тривалості доставки вантажів, їх збереженні, собівартості перевезень, потребі в інвестиціях. Інфраструктурна безпека залізничного транспорту важлива як для успішної та довготривалої роботи самого господарюючого суб'єкта, так i для економіки країни в цілому.

\section{ПЕРЕЛІК ВИКОРИСТАНИХ ДЖЕРЕЛ}

1 COUNCIL DIRECTIVE 2008/114/EC of 8 December 2008 on the identification and desigA nation of European critical infrastructures and the assessment of the need to improve their proA tection // Official Journal of the European Union, 03.12.2008.

2 Дикань В.Л. Комплексна методика визначення рівня економічної безпеки, оцінки ризиків та ймовірності банкрутства підприємства [Текст]: монографія / В.Л. Дикань, І.Л. Назаренко Харків:УкрДАЗТ, 2010. - 142 с

3 Дикань В.Л. Специфические особенности системы обеспечения экономической безопасности железнодорожного транспорта [Текст] / В.Л.Дикань, И.В.Воловельская // 
Науковий вісник Херсонського // Известия ПГУПС. - 2013. - № 1. - С.12державного університету. Серія: 15

Економічні науки.- 2016. - Вип. 16 - С. 8 Касьянова Н. В. Інфраструктурна 63-66.

4 Назаренко І.Л. Методика оцінки безпека промисловості України / Н. В. Касьянова, О. К. Біленко // Проблеми рівня економічної безпеки дистанції колії [Текст] / І.Л. Назаренко, Т.Г. Сухорукова // Вісник економіки транспорту i промисловості. -2014. - № 48. - С. 64-69.

5 Толстова А. В. Залізничний комплекс України як основа економічної безпеки країни [Текст]/ А.В. Толстова // Вісник економіки транспорту i промисловості. - 2012. - №37. - С. 75-78.

6 Журавлева Н.А. Финансовоэкономическая безопасность инфраструктуры: вопросы теории и методологии [Текст]: автореф. дис. ... д-р экон. наук. 08.00.05/ Н.А.Журавлева. СПб., 2010. - 41 с.

7 Журавлева Н.А. Экологическая безопасность транспортной инфраструктуры [Текст] / Н.А. Журавлева формування та розвитку інноваційної інфраструктури: європейський вектор нові виклики та можливості: тези доповідей III Міжнародної науковопрактичної конференції. Львів: Видавництво Львівської політехніки, 2015. - C. 162-163.

9 Технічний регламент безпеки інфраструктури залізничного транспорту [Електронний ресурс]. - Режим доступу: http://zakon3.rada.gov.ua/laws/show/4942013-\%D0\%BF

10 Шраменко О.В. Забезпечення інфраструктурної безпеки залізничного транспорту [Текст] / О.В.Шраменко // Вісник економіки транспорту i промисловості. - 2016. - № 56. - С.113118. 